This is the peer reviewed version of the following article: Larsson, M.A., Baken, S., Gustafsson, J.P., Hadialhejazi, G., Smolders, E. 2013. Vanadium bioavailability and toxicity to soil microorganisms and plants. Environmental Toxicity and Chemistry 32, 2266-2273, which has been published in final form at http://dx.doi.org/10.1002/etc.2322. This article may be used for non-commercial purposes in accordance with Wiley Terms and Conditions for self-archiving.

\title{
VANADIUM BIOAVAILABILITY AND TOXICITY TO SOIL MICROORGANISMS AND PLANTS
}

Maja A. Larsson, *†, Stijn BaKen, $\ddagger$, Jon Petter Gustafsson, §†, Golshid Hadialhejazi, § and ERIK SMOLDERS $\ddagger$

†Department of Soil and Environment, Swedish University of Agricultural Sciences, Uppsala, Sweden

$\ddagger$ Division of Soil and Water Management, Department of Earth and Environmental Sciences, Katholieke Universiteit Leuven, Leuven, Belgium

§Department of Land and Water Resources Engineering, Royal Institute of Technology, Stockholm, Sweden

*Adress correspondence to maja.larsson@slu.se 


\begin{abstract}
Vanadium, V, is a redox-sensitive metal that in solution, under aerobic conditions, prevails as the oxyanion vanadate(V). There is little known regarding vanadium toxicity to soil biota and the present study was set up to determine the toxicity of added vanadate to soil organisms and to investigate the relationship between toxicity and vanadium sorption in soils. Five soils with contrasting properties were spiked with 7 different doses (3.2-3200 mg V kg-1) of dissolved vanadate, and toxicity was measured with 2 microbial and 3 plant assays. The EC50 thresholds (50\% adverse effect) of the microbial assays ranged from 28 to $690 \mathrm{mg}$ added $\mathrm{V} \mathrm{kg}^{-1}$ and the EC50s in the plant assays ranged from 18 to $510 \mathrm{mg}$ added $\mathrm{V} \mathrm{kg}^{-1}$. The lower thresholds were in the concentration range of the background vanadium in the untreated control soils (15-58 $\mathrm{mg} \mathrm{V} \mathrm{kg}^{-1}$ ). The vanadium toxicity to plants decreased with a stronger soil vanadium sorption strength. The EC50 values for plants expressed on soil solution basis ranged from. 0.8 to $15 \mathrm{mg}$ $\mathrm{V} \mathrm{L}^{-1}$ and were less variable among soils than corresponding values based on total vanadium in soil. It is concluded that sorption decreases the toxicity of added vanadate and that soil solution vanadium is a more robust measure to determine critical vanadium concentrations across soils.
\end{abstract}

Keywords: Vanadium, Vanadate, Sorption, Toxicity, Bioavailability 


\section{INTRODUCTION}

Vanadium, V, is a transition metal rather evenly distributed within the Earth’s crust. In European topsoils, the average aqua regia-soluble vanadium concentration is $38 \mathrm{mg} \mathrm{V} \mathrm{kg}{ }^{-1}$ [1]. The most important anthropogenic sources of vanadium are associated with the burning of fossil fuels, and its main field of application is in the steel industry, in alloys. Vanadium can exist in a range of oxidation states, from +2 to +5 [2]. In solution, under environmental conditions, mainly vanadium(IV) and vanadium(V) are present [3]. Vanadium(IV), also referred to as vanadyl, is an oxocation that occurs in moderately reducing environments [4]. Under more aerobic conditions, the oxocation of vanadium(V), $\mathrm{VO}_{2}{ }^{+}$, prevails at solution $\mathrm{pH}$ below 4 whereas the oxyanion vanadate(V), $\mathrm{H}_{2} \mathrm{VO}_{4}{ }^{-}$, dominates above that $\mathrm{pH}$ [2]. Structurally, vanadate resembles phosphate and can inhibit phosphate metabolizing systems [5].

Vanadium toxicity to soil biota is relatively unexplored. Inhibition of nitrification and nitrogen mineralization has been observed at a dose of $250 \mathrm{mg} \mathrm{V} \mathrm{kg}^{-1}$ soil on the short-term [6, 7] whereas no such effects were found in a long-term (9 years) contaminated soil [8]. Toxicity of vanadium to plants has mainly been studied in nutrient solution and toxicity starts between 1and $5 \mathrm{mg} \mathrm{V} \mathrm{L}{ }^{-1}$ for the most sensitive species $[9,10]$. This concentration is well above vanadium concentrations in soil solution that typically are below $0.01 \mathrm{mg} \mathrm{V} \mathrm{L}^{-1}$ [11]. In pot trials with spiked soils, there were no toxic effects to collard grown in a loamy sandy soil at the highest dose of $100 \mathrm{mg} \mathrm{V} \mathrm{kg}^{-1}$. However, collard biomass reduction was observed in a sandy soil at 80 $\mathrm{mg} \mathrm{V} \mathrm{kg}{ }^{-1}$ [10]. Growth of soybean seedlings was affected at $30 \mathrm{mg} \mathrm{V} \mathrm{kg}^{-1}$ in one soil whereas no effects were found up to $75 \mathrm{mg} \mathrm{V} \mathrm{kg}^{-1}$ in another soil [12]. Toxicity of vanadium to barley and tomato, i.e. 50 \% reduced growth, was found at concentrations ranging from 31 to $510 \mathrm{mg}$ added 
$\mathrm{V} \mathrm{kg}^{-1}$ in 3 different soils. Ageing after spiking reduced toxicity and extractable vanadium [13]. None of the above-mentioned studies assessed the effect of soil properties on vanadium toxicity.

Soil properties clearly affect the fate of vanadium in soil. It is mainly iron and aluminum (hydr)oxides that determine vanadium mobility in soils and waters [14-16], and there are indications that vanadate binds somewhat stronger to iron (hydr)oxides than phosphate [17]. Furthermore, vanadyl can form strong complexes with organic matter and in the presence of organic substances vanadium(V) may be reduced to vanadium(IV), especially at low pH [18]. Gäbler et al. [11] evaluated the Freundlich sorption parameters for 30 different German soils to which vanadium(V) was added. The concentrations of oxalate-soluble iron, as well as clay and organic matter content, were positively correlated to the vanadium sorption strength of the soils. In 3 Finnish mineral soils, the maximum vanadium(V) adsorption was observed at approximately $\mathrm{pH} 4$ [19].

The aim of the present study was to assess the toxicity of freshly added vanadate in soils to different soil organisms and to investigate the relationship between toxicity and vanadium sorption in soils. Five European soils with different properties were spiked with vanadate, toxicity was measured and soil solutions were analyzed for dissolved vanadium. The hypothesis was that lower toxic effects would be observed in response to added vanadate in soils with a strong vanadium sorption. The toxicity to soil microbes was examined using standard assays for nitrification and respiration. Plant toxicity studies were conducted with tomato (Lycopersicon Esculentum Miller) and barley (Hordeum vulgare L.). 


\section{MATERIALS AND METHODS}

\section{Soil properties}

Five European top soils, selected to cover different soil textures, metal (hydr)oxide content and pH, were sampled between 2007 and 2010 (Table 1). The soils were collected with a spade down to $20 \mathrm{~cm}$ depth, air-dried at $20-30{ }^{\circ} \mathrm{C}$ and sieved (4 mm). A $2 \mathrm{~mm}$ sieve was used for the Pustnäs and Säby soils. The soils were stored in plastic containers until further use.

Soil properties were determined simultaneously for all soils. The soil $\mathrm{pH}$ was measured in a $0.01 \mathrm{M} \mathrm{CaCl}_{2}$ extract with a soil:solution ratio of 1:5 and an equilibration time of 2 hours. The organic carbon content was determined by oxidative digestion at $900^{\circ} \mathrm{C}$ (EA 1110, CE instruments). The carbonate content was measured from developed pressure after adding $\mathrm{HCl}$ to the soil in closed vessels containing $\mathrm{FeSO}_{4}$ as a reducing agent [20]. Soil texture was established using the pipette method according to ISO 11277 guidelines [21] and the effective cation exchange capacity (eCEC) was measured by means of the silver thiourea (AgTU) method [22]. The vanadium concentrations of the soils were determined by aqua regia digestion and vanadium concentrations were determined with ICP-OES at $290.880 \mathrm{~nm}$ (Inductively Coupled Plasma Optical Emission Spectroscopy, Perkin Elmer, Optima 3300 DV). Duplicates of one standard reference sample with a certified aqua regia-digestible vanadium concentration (NRC Canada LKSD-4) or one soil reference sample from WEPAL international soil-analytical exchange program (WEPAL 921) were included in each batch of maximum 98 samples. The recovery ranged from 88 to $105 \%$ of certified vanadium concentrations in all 6 reference samples except for one replicate of WEPAL 921. Plant-available phosphorous was determined by ammonium lactate extraction (P-AL) [23] and oxalate-extractable Fe, $\mathrm{Al}$ and Mn were extracted in darkness 
using a $0.2 \mathrm{M}$ ammonium oxalate solution (solid:liquid ratio 1:50) at $\mathrm{pH} 3 \mathrm{for} 2 \mathrm{~h}$ followed by ICP-OES analysis.

\section{Soil spiking and incubation}

Prior to testing, soils were wetted and incubated (20 ${ }^{\circ} \mathrm{C}$ in darkness) for 1 week. Each soil was then spiked with a stock solution of dissolved sodium metavanadate $\left(\mathrm{NaVO}_{3}\right)$, generating a series composed of 1 control and 7 different vanadium doses (0, 3.2, 10, 32, 100, 320, 1000 and

$3200 \mathrm{mg} \mathrm{V} \mathrm{kg}^{-1}$ dry weight, dw). These doses are hereafter referred to as nominal concentrations. Metavanadate reacts quickly with water to form orthovanadate, i.e. $\mathrm{H}_{2} \mathrm{VO}_{4}{ }^{-}$[24]. The soils were spiked by adding appropriate volumes of a concentrated stock solution of $25 \mathrm{~g} \mathrm{~V} \mathrm{~L}^{-1}$.To obtain the highest test concentration, a saturated suspension of $80 \mathrm{~g} \mathrm{~V} \mathrm{~L}^{-1}$ was added. The soil water content was then increased to $75 \%$ and all samples were thoroughly mixed, and thereafter incubated for another week before commencing the assays.

Soil vanadium concentrations were determined by aqua regia digestions for all soils and vanadium doses (see method above), except for Zwijnaarde in the respiration assay. The soil vanadium concentrations that were further used in the dose-response analysis were referred to as “added vanadium” and represented the difference in aqua regia-extractable vanadium between a spiked and unspiked control soil. The recovery of added vanadium ranged from 70 to $100 \%$ of the nominal dose at concentrations of $32 \mathrm{mg} \mathrm{V} \mathrm{kg}^{-1}$ and above. At the nominal doses of 3.2 and $10 \mathrm{mg} \mathrm{V} \mathrm{kg}^{-1}$, the recovery varied widely due to interferences with the vanadium background concentrations of the soils (ranging from 15 to $58 \mathrm{mg} \mathrm{V} \mathrm{kg}^{-1}$ ). The added concentrations were therefore set to the nominal levels for these two concentrations in the dose-response analysis. 


\section{Microbial assays}

The potential nitrification rate (PNR) assay was performed according to the international standard ISO 14238 [25]. Soils (100 \pm 5.0 g) were added to plastic pots and mixed with $100 \mathrm{mg}$ $\mathrm{kg}^{-1}$ of $\mathrm{NH}_{4}-\mathrm{N}$ (stock solution of $\left.80 \mathrm{~g} \mathrm{~L}^{-1}\left(\mathrm{NH}_{4}\right)_{2} \mathrm{SO}_{4}\right)$. The pots were stored in darkness at $20{ }^{\circ} \mathrm{C}$ , and 3 subsamples of $2.5 \pm 0.05$ g were taken after 0,7 and 28 days. The subsamples were extracted with $10 \mathrm{ml} 1 \mathrm{M} \mathrm{KCl}$ for $2 \mathrm{~h}$ in an end-over-end shaker, followed by centrifugation for 15 min at $3000 \mathrm{~g}$. The $\mathrm{NO}_{3}{ }^{-}$concentrations of the supernatant were measured colorimetrically (SA40; Skalar, Delft, The Netherlands). The PNR was calculated from the increase of $\mathrm{NO}_{3}{ }^{-}$ concentrations during the first 7 days and expressed as $\mu g \mathrm{NO}_{3}-\mathrm{N} \mathrm{g}^{-1}$ day $^{-1}$. The PNR in the Zwijnaarde soil was calculated based on concentrations measured after 28 days due to the low nitrification activity.

The substrate induced respiration (SIR) assay was performed according to the OECD 217 carbon transformation test [26]. Briefly, $5 \pm 0.05 \mathrm{~g}$ of vanadium spiked soils were weighed into a $20 \mathrm{ml}$ vial in triplicate. A spike of $0.125 \mathrm{ml}$ of $40 \mathrm{~g}$ glucose $\mathrm{L}^{-1}$ solution, labelled with ${ }^{14} \mathrm{C}$ glucose, was added to each vial and mixed thoroughly. The open vials were placed in a Schott bottle containing $5 \mathrm{ml}$ of $1 \mathrm{M} \mathrm{NaOH}$ to trap evolved ${ }^{14} \mathrm{CO}_{2}$. The bottles were tightly closed and incubated at $20^{\circ} \mathrm{C}$ in darkness. After 24 hours, $1 \mathrm{ml}$ of the $\mathrm{NaOH}$ trap was sampled and $4 \mathrm{ml}$ scintillation cocktail (Ultima Gold, Perkin Elmer, Boston, MA, USA) was added and mixed. The

${ }^{14} \mathrm{C}$ activity was subsequently measured by beta scintillation counting (Tri Carb 2800 Tr, Perkin Elmer). The SIR was calculated based on the amount of labelled glucose respired per gram soil and day. 


\section{Plant assays}

The 5-day root elongation test was performed with barley according to the international standard ISO 11269-1 [27]. Triplicate samples of each soil and treatment were weighed ( 500 g) and added to plastic pots, in which 10 germinated barley seeds were placed just below the soil surface. The soils were then covered with $1 \mathrm{~cm}$ of polypropylene beads to reduce water losses through evaporation. The pots were placed in a randomized fashion in a growth chamber, and subjected to a $16 \mathrm{~h}$ light and an $8 \mathrm{~h}$ dark cycle with $20^{\circ} \mathrm{C}$ during the light hours and $16^{\circ} \mathrm{C}$ during the dark hours. The humidity was set to $70 \%$, and the light intensity to $650 \mathrm{~mol}$ photons $\mathrm{m}^{-2} \mathrm{~s}^{-1}$. When the seedlings emerged, they were reduced to 5 individuals, which were left to grow for 5 days. The pots were watered on a daily basis by weighing each pot and replacing the water loss. After 5 days of growing, the plants were removed from the soil and the length of the longest root was recorded for each plant. A mean value of the longest root was calculated per pot and replicate.

Shoot growth assays were performed with summer barley and tomato according to ISO 11269-2 [28]. The soils were fertilized with $50 \mathrm{mg} \mathrm{P} \mathrm{kg}^{-1}$ (as $\mathrm{KH}_{2} \mathrm{PO}_{4}$ ) and with $100 \mathrm{mg} \mathrm{N} \mathrm{kg}^{-1}$ (as $\mathrm{KNO}_{3}$ ) directly after vanadium spiking. Four pots with each $500 \mathrm{~g}$ of soil were used for every treatment. The barley seeds were germinated before sowing (10 per pot), whereas the tomato seeds (20 per pot) were planted ungerminated. The pots were then covered with polypropylene beads to reduce water losses, placed in a randomized fashion in a growth cabinet, and subjected to the same conditions as described above. When seedlings emerged above the surface (after 3 days for barley and after 8 to 11 days for tomato), they were reduced to five individuals per pot. The plants were then left to grow from 12 to 14 days with daily watering. After the growing 
period, the plants were cut just above the surface, air-dried at $70^{\circ} \mathrm{C}$ and then weighed to determine the dry plant weight in each pot.

\section{Soil solution extraction analysis}

Soil solution extractions were performed in duplicate from samples used in the barley shoot growth assay, applying the centrifugation method used by Merckx et al. [29]. The soils were adjusted to a water holding capacity of 80-90 \% relative to that of their field capacity (pF 2.0), and then incubated for 3 days before the extraction. The control soils and the treatments adjacent to the EC50 threshold values (see below) were extracted. The solutions were filtered $(0.45 \mu \mathrm{m})$ and then analyzed for $\mathrm{pH}$, major cations (ICP-OES) and anions (ion chromatography, Dionex ICS2000 with AS15 column), non-purgeable organic carbon, and inorganic carbon (using an Analytik Jena Multi N/C 2100 instrument).

\section{Soil sorption isotherms}

Vanadium sorption to the soils was determined by batch experiments. In brief, $2.00 \pm$ $0.05 \mathrm{~g}$ of air dried soil were added to polypropylene bottles together with a $30 \mathrm{ml}$ solution containing $0.01 \mathrm{M} \mathrm{NaNO}_{3}$ and seven different concentrations of vanadate (ranging from 0 to 15

mg V L ${ }^{-1}$ ). The vanadate stock solution was made using $\mathrm{NaVO}_{3}$ salt. The tubes were equilibrated in room temperature in an end-over-end shaker for 6 days and the samples were thereafter centrifuged in $4000 \mathrm{~g}$ for $15 \mathrm{~min}$. The supernatant was then removed and a subsample was taken to measure its $\mathrm{pH}$. The remaining of the supernatant was filtered with a $(0.2 \mu \mathrm{m})$ and analyzed for vanadium with inductively coupled plasma mass spectroscopy (ICP-MS; Varian-Vista Australia Pty. Ltd., Clayton, Victoria, Australia). 
The obtained results were fitted to the Freundlich equation

$$
n=K_{F} \times c^{m}
$$

Here, $n\left(\mathrm{mg} \mathrm{kg}^{-1}\right)$ is the total concentration of sorbed vanadium, which is the sum of the vanadium sorbed during the experiment $\left(n_{\text {sorb }}\right)$ and the initially sorbed vanadium $\left(n_{\text {ini }}\right)$. In addition, $c\left(\mathrm{mg} \mathrm{L}^{-1}\right)$ is the measured dissolved vanadium concentration, whereas $K_{F}$ (the Freundlich coefficient) and $m$ (non-ideality parameter) are adjustable parameters. The value of $n_{\text {ini }}$ was fitted [30]. In the fitting procedure, $n_{i n i}, K_{F}$ and $m$ were optimized through trial-and-error, which involved linear regression on log-transformed values using the trendline tool in Microsoft Excel.

Statistical analysis

The EC50 values of the added vanadium concentration ( $X$, in $\mathrm{mg} \mathrm{V} \mathrm{kg}^{-1}$ ) at which a $50 \%$ reduction in response $Y$ occurred were determined with a log-logistic dose-response model

$$
Y=\frac{C}{1+\exp \left(b \times \ln \frac{X}{E C_{50}}\right)}
$$

The model parameters, together with standard errors, were determined with the Marquardt method (SAS ${ }^{\circledR}, 9.02$, SAS institute, Cary, NC, USA). In Equation 2, the $C$ parameter is the response in the control soils (e.g. dry weight of plant) and $b$ is the slope parameter.

The EC10 values (10 \% reduction in response) were estimated according to

$$
Y=\frac{C}{1+\frac{1}{9} \exp \left(b \times \ln \frac{X}{E C_{10}}\right)}
$$


The parameters and standard errors of the EC10 values were determined with the same procedure as applied for the EC50 values. The soil solution EC50 values, i.e. the vanadium concentration of the soil solution at which a $50 \%$ response reduction was observed, were estimated by linear interpolation between the soil solution vanadium concentrations in the two soil treatments bracketing the EC50 value (mg V kg-1).

A single-sided t-test with $95 \%$ confidence limit was used to determine differences in threshold values (EC10 and EC50) among soils. All combinations of soils were tested pairwise and the same test was performed to determine any difference in sensitivity among the plant assays. Pearson correlations between EC50 values and soil properties were determined by using the statistical program Minitab 16.

\section{RESULTS}

\section{Vanadium sorption properties}

The vanadium sorption properties differed among the 5 soils as shown by the Freundlich sorption isotherms (Figure 1). Fitted values of the initial vanadium soil concentration $n_{\text {ini }}$, the Freundlich coefficient $K_{F}$ and the non-ideality parameter $m$ are listed in Table 2. In each soil, the $\mathrm{pH}$ value remained constant with a difference smaller than 0.2 units in response to the different vanadium additions (Table 2). Further, the vanadium concentrations in solution for samples without added vanadium were low and ranged from 0.003 (Guadalajara) to $0.054 \mathrm{mg} \mathrm{V} \mathrm{L}^{-1}$ (Zwijnaarde). To compare the vanadium sorption properties of the soils, the "Freundlich sorption strength” was determined, which was defined as the amount of sorbed vanadium expected when 
the dissolved vanadium concentration was $2.5 \mathrm{mg} \mathrm{L}^{-1}$. The concentration was chosen to comply with the median soil solution EC50 of $2.6 \mathrm{mg} \mathrm{V} \mathrm{L}^{-1}$ (see below). The sorption strength varied about 10-fold between the soils, where the Säby soil had the highest sorption strength and Zwijnaarde the lowest. Saturation of the sorption sites (as would be evidenced by flattening of the Freundlich $\log n-\log c$ graph at high concentrations) was not reached in the vanadium concentration range tested.

\section{Vanadium toxicity}

\section{Microbial assays}

The microbial activity in the untreated control soils varied by a factor of 5 in the PNR assay and by a factor of 20 in the SIR assay, indicating that the conditions for the microbial population differed among the soils (Table 3). There was a negative response to increasing soil vanadium concentrations in all toxicity assays; hormesis effects were not observed. However, the toxic concentration was clearly different depending on the soil. In the PNR assay, EC50 values ranged from 28 (Zwijnaarde) to $690 \mathrm{mg} \mathrm{V} \mathrm{kg}^{-1}$ (Säby), i.e. a 24-fold difference between the highest and lowest threshold value. The EC50s in the SIR assay ranged from 200 (Pustnäs) to $580 \mathrm{mg} \mathrm{V} \mathrm{kg}^{-1}$ (Guadalajara). The PNR EC10 values were all in the range of the vanadium background concentrations with the exception of the Säby soil. Due to the low nitrification rate in the Zwijnaarde soil, the sensitivity to toxic effects was low after 7 days and substrate limitations were not yet observed after 28 days. Many of the SIR thresholds were uncertain with large standard errors. For example, the SIR EC10 of the Ter Munck soil had a standard error larger than the threshold value. 
There was no correlation between vanadium sensitivity and soil properties in the two microbial assays. For instance, the microbial population in the Guadalajara soil was more sensitive to vanadium in the PNR assay then in the Säby soil. The opposite was observed in the SIR assay, for which the vanadium sensitivity was higher in the Säby soil compared to Guadalajara (Table 3 and Figure 2).

\section{Plant assays}

The average barley root length in the untreated control soils was similar in all soils (Table 4). In the shoot growth assay, the biomass yield in the untreated soils varied between 0.49 and $1.06 \mathrm{~g} \mathrm{dw}$ for barley and between 1.02 and $1.79 \mathrm{~g} \mathrm{dw}$ for tomato. However, the Guadalajara soil was not included in the tomato shoot growth assay due to unsuccessful emergence $(<70 \%)$. The EC10 values within the different plants assays varied by a factor ranging from 7 to 10 and the range of EC50 values was a factor of 4 to 10 between the highest and lowest value. The lowest EC50 values were obtained in the tomato shoot growth assay whereas the highest were recorded in the root elongation assay (single sided t-test, $p<0.05$ ). The EC10 and EC50 values, covering all 3 plant assays, were generally highest in Säby, and lowest in the Zwijnaarde soil. However, forthe barley and tomato shoot growth assays, the EC10 values of the Zwijnaarde soil were not different from the EC10 values of the Pustnäs soil (single sided t-test, $p<0.05$ ).

\section{Soil solution}

The vanadium toxicity thresholds of the plant assays were positively correlated with the vanadium sorption strength of the soils (Table 5). Only five soils were studied, but soils with a stronger vanadium sorption also had higher EC50 values (i.e. comparably lower toxicity), see 
Figure 3. In terms of the soil $\mathrm{pH}$, the Guadalajara soil differed from the other soils having a high $\mathrm{pH}$ (7.8). This was related to its carbonate content of $23 \%$. The EC50 values correlated well to oxalate-extractable iron in all 3 plant assays (Pearson $r>0.97, p<0.05$, Figure 3 ) when the data from the Guadalajara soil was excluded from the linear regression analysis.

The vanadium concentrations in soil solution of the untreated control soils ranged from 0.006 to $0.1 \mathrm{mg} \mathrm{L}^{-1}$. The difference in the EC50 thresholds among soils was smaller when expressed as soil solution vanadium than when expressed as the added vanadium concentration (Table 4). The EC50s in soil solution varied by a factor of 6 in the root elongation assay, by a factor of 3 in the barley shoot growth assay and by a factor of 2 in the tomato shoot growth assay. When based on the added vanadium concentrations the corresponding threshold values varied by a factor of 7, 4 and 10 respectively. In addition, the coefficient of variation (CV) of the EC50s was consistently lower when expressed as dissolved than as added vanadium (Table 4). The plots in Figure 4 illustrate the dose-response curves of the relative response (root length relative to control in \%), including all soils in the root elongation assay. The adjusted $R^{2}$, which describes the goodness-of-fit, was higher when the vanadium concentrations were expressed as soil solution vanadium (0.94) then when expressed as the total vanadium concentration in the soil (0.74). In other words, vanadium concentrations in soil solution are a better index for vanadium toxicity than the total soil vanadium concentration. 


\section{DISCUSSION}

The present study highlighted that the toxicity of vanadium among different soils decreases as the sorption strength increases. Before elaborating on this, we first compare the toxic thresholds with those obtained in other studies.

The total or added EC10 thresholds, expressed as $\mathrm{mg} \mathrm{V} / \mathrm{kg}$ soil, for microbial processes were in the range of natural vanadium background concentrations, and sometimes even lower. There are few studies conducted on vanadium toxicity to soil microorganisms, but Liang and Tabatabai [7] observed between 12 and $62 \%$ inhibition of nitrification in three different soils at vanadium concentrations of $250 \mathrm{mg} \mathrm{kg}^{-1}$ soil. This agrees rather well with the EC50 values obtained in this study that were both below and above $250 \mathrm{mg} \mathrm{V} \mathrm{kg}^{-1}$ soil (Table 3). Wilke [8] observed no negative effects of vanadium concentrations of $122 \mathrm{mg} \mathrm{kg}^{-1}$ soil (aqua regia) on nitrification in a sandy cambisol. However the study was made on a long-term basis. Hence it is possible that bacteria adapted to the vanadium, and in addition vanadium might have become less bioavailable over time.

In the plant assays, the root elongation test was the least sensitive among the three tests. This may seem surprising since vanadium mainly accumulates in the roots [31, 32]. However, the root elongation assay was performed for a shorter period of time than the shoot growth assay (5 days and 14 days, respectively), and toxic effects may increase with exposure time [33]. Tomato plants were more sensitive than barley in the shoot growth assay. Toxicity tests performed with other metals confirms that barley as a monocotyledonous species generally is less sensitive than the dicotyoledonous tomato [34]. 
The vanadium sorption strength, at dissolved vanadium concentrations of $2.5 \mathrm{mg} \mathrm{V} \mathrm{L}^{-1}$, was strongest in the Säby soil and weakest in the Zwijnaarde soil. This may be related to the soil concentration of oxyhydroxides, especially the iron oxyhydroxides [14, 15]. Gäbler et al. [11] observed a relationship between the sorption strength (which they defined as $\log K_{\mathrm{F}}{ }^{*} m$ ) and the sum of oxalate-extractable iron, aluminium and manganese. Oxalate-extractable metals are also important for the bioavailability for other oxyanions such as molybdate and arsenate, though they are not the only controlling factors [35, 36]. In the present study, oxalate-extractable iron appeared to affect sorption strength for 4 of the soils. For the Guadalajara soil, other factors appear to have affected its vanadium sorption properties (Figure 3). The reasonably good relationship between the sorption strength and the toxicity thresholds (Figure 3) confirms that soil-specific vanadium toxicity is strongly related to sorption reactions where iron and aluminium (hydr)oxides play an important role.

Since the geogenic vanadium is less soluble than the added vanadium [13], it may be risky to estimate potential vanadium toxicity in soils based on thetotal soil concentration. An alternative approach could be to express the threshold values as dissolved vanadium. The vanadium concentrations in soil solution are affected by the sorption strength and the need to adjust for a toxicologically inert fraction of $\mathrm{V}$ in the geogenic background could be avoided by use of soil solution-based values. In addition, as Table 4 and Figure 4 illustrate, the EC50 values expressed as dissolved vanadium are more consistent between soils, i.e. there is a smaller variation than for added vanadium EC50s among soils. The soil solution thresholds would consequently provide a more accurate estimate of the toxic vanadium concentrations. Similar findings have been reported for other metals such as cobalt where the soil solution concentrations reduced the variation in threshold values among soils [34]. This confirms our earlier study, 
which reports that the ageing effects of vanadate in soil on plant toxicity are accompanied by changes in vanadium solubility over time [13], i.e. solubility explains toxicity in soils. Evaluating vanadium toxicity on a soil solution basis instead of on a soil basis appears to be a more consistent index for toxicity across different soils.

The relatively small differences among the EC50 values expressed as dissolved vanadium probably depend on a number of geochemical factors, including speciation and competition with phosphate. The main fraction of vanadium in soil solution is likely vanadate(V) since the soils were subject to aerobic conditions during the assays, and soil $\mathrm{pH}$ was above $\mathrm{pH}$ 5. A reduction of added vanadium(V) to vanadium(IV) under these conditions is not likely [2]. Also, based on the previously published study, we can assume that the main fraction of the available vanadium is vanadate(V) [13]. The presence of phosphate may reduce vanadate uptake due to competition [37] and further studies focusing on the interactions between vanadium and phosphorus in soils are required to address this issue.

To summarize, the present study reports vanadium toxicity thresholds (EC50) for higher plants, ranging from 18 to $510 \mathrm{mg} \mathrm{V} \mathrm{kg}^{-1}$ with a median of $91 \mathrm{mg} \mathrm{V} \mathrm{kg}^{-1}$, in 5 different soils. The vanadium toxicity to soil microorganisms varied among soils, potentially also affected by difference in microbial communities. Some of the lowest thresholds were in the same range as the aqua regia-soluble vanadium in untreated control soils. The differences in vanadium toxicity among soils were explained by the vanadium sorption capacities of the soils which controlled the bioavailability. Consequently, the vanadium concentration in the soil solution appeared to be a better estimate of the toxic vanadium levels than the vanadium concentrations in the soil. Plant toxicity (EC50) expressed as dissolved vanadium was observed between 0.8 and $15 \mathrm{mg} \mathrm{V} \mathrm{L}^{-1}$, 
with a median of $2.6 \mathrm{mg} \mathrm{V} \mathrm{L}^{-1}$. In conclusion, vanadium toxicity in soils is controlled by the vanadium sorption strength of the soils and is therefore better and more accurately indicated from the vanadium concentration in soil solution.

Acknowledgment The authors thank the Vanadium Consortium for funding, and A. Voigt and K. Oorts for coordinating the project. The present study may not be freely used to comply with regulatory requirements, including REACH regulation (EC) No 1907/2006, without the formal agreement of the Vanadium Consortium. We also thank SSAB Merox AB, LKAB and Rautaruukki Corporation for financial support. The Royal Swedish Academy of Agriculture and Forestry is acknowledged for covering travelling and lodging costs.

\section{REFERENCES}

[1] Salminen R, Batista MJ, Bidovec M, Demetriades A, De Vivo B, De Vos W, Duris M, Gilucis A, Gregorauskiene V, Halamic J, Heitzmann P, Lima A, Jordan G, Klaver G, Klein P, Lis J, Locutura J, Marsina K, Mazreku A, O'Connor PJ, Olsson SÅ, Ottesen R-T, Petersell V, Plant JA, Reeder S, Salpeteur I, Sandström H, Siewers U, Steenfelt A, Tarvainen T. 2005. Geochemical Atlas of Europe. Part 1: Background Information, Methodology and Maps. Espoo, Geological Survey of Finland.

[2] Baes CF, Mesmer RE. 1976. The Hydrolysis of Cations. John Wiley \& Sons, New York, USA.

[3] Wanty RB, Goldhaber MB. 1992. Thermodynamics and kinetics of reactions involving vanadium in natural systems: Accumulation of vanadium in sedimentary rocks. Geochimica Et Cosmochimica Acta 56:1471-1483.

[4] Wehrli B, Stumm W. 1989. Vanadyl in natural waters: Adsorption and hydrolysis promote oxygenation. Geochimica Et Cosmochimica Acta 53:69-77. 
[5] Seargeant LE, Stinson RA. 1979. Inhibition of human alkaline phosphatases by vanadate. Biochem J 181:247-250.

[6] Liang CN, Tabatabai MA. 1977. Effects of trace-elements on nitrogen mineralization in soils. Environ Pollut 12:141-147.

[7] Liang CN, Tabatabai MA. 1978. Effects of trace elements on nitrification in soils. $J$ Environ Qual 7:291-293.

[8] Wilke BM. 1989. Long-term effects of different inorganic pollutants on nitrogen transformations in a sandy cambisol. Biol Fert Soils 7:254-258.

[9] Carlson CL, Adriano DC, Sajwan KS, Abels SL, Thoma DP, Driver JT. 1991. Effects of selected trace-metals on germinating-seeds of 6 plant-species. Water Air Soil Pollut 59:231-240. [10] Kaplan DI, Sajwan KS, Adriano DC, Gettier S. 1990. Phytoavailability and toxicity of beryllium and vanadium. Water Air Soil Pollut 53:203-212.

[11] Gabler HE, Gluh K, Bahr A, Utermann J. 2009. Quantification of vanadium adsorption by German soils. J Geochem Explor 103:37-44.

[12] Wang JF, Liu Z. 1999. Effect of vanadium on the growth of soybean seedlings. Plant Soil 216:47-51.

[13] Baken S, Larsson MA, Gustafsson JP, Cubadda F, Smolders E. 2012. Ageing of vanadium in soils and consequences for bioavailability. Eur J Soil Sci.

[14] Naeem A, Westerhoff P, Mustafa S. 2007. Vanadium removal by metal (hydr)oxide adsorbents. Water Research 41:1596-1602.

[15] Peacock CL, Sherman DM. 2004. Vanadium(V) adsorption onto goethite (alpha-FeOOH) at pH 1.5 to 12: A surface complexation model based on ab initio molecular geometries and EXAFS spectroscopy. Geochimica Et Cosmochimica Acta 68:1723-1733. 
[16] Wallstedt T, Bjorkvald L, Gustafsson JP. 2010. Increasing concentrations of arsenic and vanadium in (southern) Swedish streams. Applied Geochemistry 25:1162-1175.

[17] Blackmore DPT, Ellis J, Riley PJ. 1996. Treatment of a vanadium-containing effluent by adsorption/coprecipitation with iron oxyhydroxide. Water Research 30:2512-2516.

[18] Lu XQ, Johnson WD, Hook J. 1998. Reaction of vanadate with aquatic humic substances: An ESR and V-51 NMR study. Environ Sci Technol 32:2257-2263.

[19] Mikkonen A, Tummavuori J. 1994. Retention of vanadium (V) by three Finnish mineral soils. Eur J Soil Sci 45:361-368.

[20] Loeppert RH, Suarez DL. 1996. Carbonate and gypsum. In Sparks DL, Page AL, Helmke PA, Loeppert RH, Soltanpour PN, Tabatabai MA, Johnston CT, Sumner ME, eds, Methods of soil analysis, Part 3 - Chemical methods. Soil Science Society of America, Madison, WI, USA, pp 437-475.

[21] Standardization IOf. 1998. Soil quality - Determination of particle size distribution in mineral soil material - Method by sieving and sedimentation. ISO 11277. International Organization for Standardization, Geneve, Switzerland, p. 38.

[22] Pleysier JL, Juo ASR. 1980. A single-extraction method using silver-thiourea for measuring exchangeable cations and effective CEC in soils with variable charges. Soil Sci 129:205-211.

[23] Egnér H, Riehm H, Domingo WR. 1960. Untersuchung über die chemische Bodenanalyse als Grundlage für die Beurteilung des Nährstoffzustandes der Böden. 2. Chemische Extraktionsmethoden zur Phosphor und Kaliumbestimmung. Ann R Agric Coll Swed 26:199-215. 
[24] Crans DC, MahroofTahir M, Keramidas AD. 1995. Vanadium chemistry and biochemistry of relevance for use of vanadium compounds as antidiabetic agents. Mol Cell Biochem 153:17-24.

[25] Standardization IOf. 1997. Soil quality - Biological methods - Determination of nitrogen mineralization and nitrification in soils and the influence of chemicals on these processes. ISO 14238. International Organization for Standardization, Geneve, Switzerland.

[26] OECD. 2000. OECD 217. Soil Microorganisms: carbon Transformation Test.

[27] Standardization IOf. 1993. Soil quality - Determination of the effects of pollutants on soil flora - Part 1: Method for the measurement of inhibition of root growth. ISO 11269-1. [28] Standardization IOf. 2005. Soil quality - Determination of the effects of pollutants on soil flora - Part 2: Effects of chemicals on the emergence and growth of higher plants. ISO 11269-2. Geneve, Switzerland.

[29] Merckx R, Brans K, Smolders E. 2001. Decomposition of dissolved organic carbon after soil drying and rewetting as an indicator of metal toxicity in soils. Soil Biol Biochem 33:235-240. [30] Fitter AH, Sutton CD. 1975. The use of the Freundlich isotherm for soil phosphate sorption data. Journal of Soil Science 26:241-246.

[31] Gil J, Alvarez CE, Martinez MC, Perez N. 1995. Effect of vanadium on lettuce growth, cationic nutrition, and yield. J Environ Sci Health Part A-Environ Sci Eng Toxic Hazard Subt Control 30:73-87.

[32] Kaplan DI, Adriano DC, Carlson CL, Sajwan KS. 1990. Vanadium - toxicity and accumulation by beans. Water Air Soil Pollut 49:81-91.

[33] Kopittke PM, Blamey FPC, Asher CJ, Menzies NW. 2010. Trace metal phytotoxicity in solution culture: a review. J Exp Bot 61:945-954. 
[34] Li HF, Gray C, Mico C, Zhao FJ, McGrath SP. 2009. Phytotoxicity and bioavailability of cobalt to plants in a range of soils. Chemosphere 75:979-986.

[35] McGrath SP, Mico C, Curdy R, Zhao FJ. 2010. Predicting molybdenum toxicity to higher plants: Influence of soil properties. Environ Pollut 158:3095-3102.

[36] Song J, Zhao FJ, McGrath SP, Luo YM. 2006. Influence of soil properties and aging on arsenic phytotoxicity. Environ Toxicol Chem 25:1663-1670.

[37] Nalewajko C, Lee K, Olaveson M. 1995. Responses of fresh-water algae to inhibitory vanadium concentrations - the role of phosphorus. J Phycol 31:332-343. 
Table 1. Soil properties of five soils used in the toxicity assays ${ }^{\mathrm{a}}$

\begin{tabular}{|c|c|c|c|c|c|c|c|c|c|c|c|c|c|}
\hline \multirow[t]{3}{*}{ Soil } & \multirow[t]{3}{*}{ Location $^{b}$} & \multirow[t]{3}{*}{ Soil Order } & \multirow[t]{3}{*}{ Land use } & \multirow[t]{3}{*}{ Sampling year } & \multirow[t]{3}{*}{$\mathrm{pH}$} & \multirow{3}{*}{$\begin{array}{l}\text { Org. C } \\
\text { (\%) }\end{array}$} & \multirow{3}{*}{$\begin{array}{l}\text { Clay } \\
\\
\text { (\%) }\end{array}$} & \multirow{3}{*}{$\begin{array}{c}\text { eCEC } \\
\left(\mathrm{cmol}_{\mathrm{c}} \mathrm{kg}^{-}\right)^{1}\end{array}$} & \multirow{3}{*}{$\begin{array}{l}\text { Tot. V } \\
\left(\mathrm{mg} \mathrm{kg}^{-1}\right)\end{array}$} & \multirow{3}{*}{$\begin{array}{c}\text { P-AL } \\
\left(\mathrm{mg} \mathrm{kg}^{-1}\right)\end{array}$} & \multicolumn{3}{|c|}{ Oxalate-extracted } \\
\hline & & & & & & & & & & & $\mathrm{Fe}$ & $\mathrm{Al}$ & $\mathrm{Mn}$ \\
\hline & & & & & & & & & & & & $\left(\mathrm{g} \mathrm{kg}^{-1}\right)$ & \\
\hline G & Guadelajara (ES) & Calcic Cambisol & Olive Orchard & 2007 & 7.8 & 0.5 & 24 & 14.1 & 17 & 58 & 0.16 & 0.44 & 0.05 \\
\hline $\mathrm{P}$ & Pustnäs (S) & Eutric Regosol & Grassland & 2009 & 5.9 & 1.1 & 11 & 4.3 & 27 & 93 & 1.43 & 0.76 & 0.13 \\
\hline S & Säby (S) & Eutric Cambisol & Arable land & 2009 & 5.5 & 2.5 & 29 & 10.2 & 58 & 41 & 4.42 & 1.25 & 0.04 \\
\hline $\mathrm{T}$ & Ter Munck (BE) & Haplic Luvisol & Arable land & 2010 & 6.6 & 0.9 & 17 & 7.3 & 38 & 141 & 2.20 & 0.58 & 0.35 \\
\hline Z & Zwijnaarde (BE) & Haplic Podzol & Arable land & 2007 & 5.2 & 1.6 & 6 & 3.0 & 15 & 225 & 0.91 & 1.17 & 0.06 \\
\hline
\end{tabular}

${ }^{\mathrm{a}}$ See Methods section for abbreviations and descriptions of analytical methods.

${ }^{\mathrm{b}} \mathrm{ES}=$ Spain; $\mathrm{BE}=$ Belgium; $\mathrm{S}=$ Sweden 
Table 2. Optimized Freundlich adsorption parameters

\begin{tabular}{|c|c|c|c|c|c|}
\hline Soil $^{\mathrm{a}}$ & $\mathrm{pH}$ range & $\mathrm{K}_{\mathrm{F}}^{\mathrm{b}}$ & $\mathrm{m}^{\mathrm{c}}$ & $\begin{array}{c}\mathrm{n}_{\mathrm{ini}}{ }^{\mathrm{d}} \\
\left(\mathrm{mg} \mathrm{V} \mathrm{kg}{ }^{-1}\right)\end{array}$ & $\mathrm{r}^{2}$ \\
\hline G & $8.06-8.24$ & 26.0 & 0.66 & 0.61 & 0.999 \\
\hline $\mathrm{P}$ & $6.26-6.40$ & 37.4 & 0.55 & 1.68 & 0.999 \\
\hline S & $5.81-5.96$ & 188 & 0.51 & 10.7 & 0.999 \\
\hline $\mathrm{T}$ & $6.60-6.72$ & 32.1 & 0.66 & 1.94 & 0.990 \\
\hline Z & $5.72-5.78$ & 13.3 & 0.70 & 2.55 & 0.999 \\
\hline
\end{tabular}

\footnotetext{
${ }^{\mathrm{a}}$ See Table 1 for abbreveations.

${ }^{b} K_{F}$ is the Freundlich coefficient which was calculated with the concentration units $\mathrm{mg} \mathrm{kg}^{-1}$ and $\mathrm{mg} \mathrm{L}^{-1}$ for $\mathrm{n}$ and $\mathrm{c}$, see Equation 1.
}

${ }^{\mathrm{c}} \mathrm{m}$ is the non-ideality parameter.

${ }^{d} n_{\text {ini }}$ is the initially sorbed vanadium concentration. 
Table 3. Vanadium toxicity thresholds (EC10 and EC50) for microorganisms in five soils, based on the added vanadium concentration with standard error shown

\begin{tabular}{|c|c|c|c|c|c|c|}
\hline \multirow[t]{3}{*}{ Soil $^{\mathrm{a}}$} & \multicolumn{3}{|c|}{ PNR } & \multicolumn{3}{|c|}{ SIR } \\
\hline & Control $^{b}$ & EC10 & EC50 & Control $^{b}$ & EC10 & EC50 \\
\hline & $\left(\mu \mathrm{g} \mathrm{NO}_{3}-\mathrm{N} \mathrm{g}^{-1} \mathrm{~d}^{-1}\right)$ & $\left(\mathrm{mg} \mathrm{V} \mathrm{kg}{ }^{-1}\right)$ & $\left(\mathrm{mg} \mathrm{V} \mathrm{kg}{ }^{-1}\right)$ & $\left(\mu\right.$ g glucose $\left.\mathrm{g}^{-1} \mathrm{~d}^{-1}\right)$ & $\left(\mathrm{mg} \mathrm{V} \mathrm{kg}{ }^{-1}\right)$ & $\left(\mathrm{mg} \mathrm{V} \mathrm{kg}^{-1}\right)$ \\
\hline $\mathrm{G}$ & $11.5 \pm 0.7$ & $19 \pm 4$ & $130 \pm 11$ & $46 \pm 5$ & $58 \pm 26$ & $580 \pm 97$ \\
\hline $\mathrm{P}$ & $2.3 \pm 0.2$ & $14 \pm 3$ & $100 \pm 8$ & $321 \pm 13$ & $10 \pm 4$ & $200 \pm 28$ \\
\hline S & $4.7 \pm 0.1$ & $190 \pm 30$ & $690 \pm 46$ & $502 \pm 70$ & $24 \pm 11$ & $320 \pm 57$ \\
\hline $\mathrm{T}$ & $10.2 \pm 0.2$ & $35 \pm 8$ & $330 \pm 30$ & $190 \pm 13$ & $8.4^{\mathrm{c}}$ & $320 \pm 133$ \\
\hline Z & $2.1^{\mathrm{d}} \pm 0.1$ & $2.2^{\mathrm{d}} \pm 0.7$ & $28^{\mathrm{d}} \pm 4$ & $25 \pm 2$ & $26^{\mathrm{e}} \pm 15$ & $220^{\mathrm{e}} \pm 50$ \\
\hline
\end{tabular}

\footnotetext{
${ }^{\mathrm{a}}$ See Table 1 for abbreviations.

${ }^{\mathrm{b}}$ Microbial responses in uncontaminated control soils with standard deviation $(\mathrm{n}=3)$.

${ }^{\mathrm{c}}$ Standard error $>$ threshold value.

${ }^{\mathrm{d}}$ Value was based on 28 observation days, see text.

${ }^{\mathrm{e}}$ Threshold value is based on nominal vanadium concentrations.

PNR=Potential Nitrification Rate

SIR=Substrate Induced Respiration
} 
Table 4. Vanadium toxicity thresholds for barley and tomato plants in five soils, based on the vanadium concentration added to the soil (add. V) with standard error shown and the vanadium concentration in soil solution (s.s. V)

\begin{tabular}{|c|c|c|c|c|c|c|c|c|c|c|c|c|}
\hline \multirow[t]{5}{*}{ Soil $^{\mathrm{a}}$} & Root lengt & & & & \multicolumn{8}{|c|}{ Shoot growth } \\
\hline & \multicolumn{4}{|l|}{ Barley } & \multicolumn{4}{|l|}{ Barley } & \multicolumn{4}{|l|}{ Tomato } \\
\hline & \multirow[t]{2}{*}{ Control $^{\mathrm{b}}$} & \multirow{2}{*}{$\begin{array}{l}\text { EC10 } \\
\text { add. V }\end{array}$} & \multicolumn{2}{|l|}{ EC50 } & \multirow[t]{2}{*}{ Control } & \multirow{2}{*}{$\begin{array}{l}\text { EC10 } \\
\text { add. V }\end{array}$} & \multicolumn{2}{|l|}{ EC50 } & \multirow[t]{2}{*}{ Control } & \multirow{2}{*}{$\begin{array}{l}\text { EC10 } \\
\text { add. V }\end{array}$} & \multicolumn{2}{|l|}{ EC50 } \\
\hline & & & add V & s.s. V & & & add. V & s.s. V & & & add. V & s.s. V \\
\hline & $(\mathrm{cm})$ & $\left(\mathrm{mg} \mathrm{kg}^{-1}\right)$ & $\left(\mathrm{mg} \mathrm{kg}^{-1}\right)$ & $\left(\mathrm{mg} \mathrm{L}^{-1}\right)$ & $(\mathrm{g} \mathrm{dw})$ & $\left(\mathrm{mg} \mathrm{kg}^{-1}\right)$ & $\left(\mathrm{mg} \mathrm{kg}^{-1}\right)$ & $\left(\mathrm{mg} \mathrm{L}^{-1}\right)$ & $(\mathrm{g} \mathrm{dw})$ & $\left(\mathrm{mg} \mathrm{kg}^{-1}\right)$ & $\left(\mathrm{mg} \mathrm{kg}^{-1}\right)$ & $\left(\mathrm{mg} \mathrm{L}^{-1}\right)$ \\
\hline G & $10.1 \pm 0.4$ & $70 \pm 3$ & $160 \pm 4$ & 15.4 & $0.49 \pm 0.01$ & $28 \pm 4$ & $80 \pm 5$ & 3.5 & n.d. & n.d. & n.d. & n.d. \\
\hline $\mathrm{P}$ & $11.5 \pm 0.3$ & $56 \pm 4$ & $110 \pm 4$ & 5.5 & $0.71 \pm 0.07$ & $20 \pm 6$ & $87 \pm 12$ & 2.4 & $1.02 \pm 0.04$ & $11 \pm 2$ & $31 \pm 2$ & 0.8 \\
\hline S & $11.2 \pm 0.3$ & $250 \pm 16$ & $510 \pm 18$ & 7.4 & $1.06 \pm 0.11$ & $98 \pm 20$ & $230 \pm 15$ & 1.5 & $1.12 \pm 0.06$ & $110 \pm 36$ & $180 \pm 25$ & 1.1 \\
\hline Z & $12.3 \pm 0.8$ & $24 \pm 3$ & $74 \pm 4$ & 5.5 & $0.81 \pm 0.03$ & $14 \pm 3$ & $54 \pm 4$ & 4.0 & $1.79 \pm 0.10$ & $11 \pm 1$ & $18 \pm 1$ & 1.3 \\
\hline $\mathrm{CV}^{\mathrm{C}}$ & & & 0.87 & 0.66 & & & 0.65 & 0.43 & & & 1.04 & 0.23 \\
\hline
\end{tabular}

${ }^{\mathrm{a}}$ See Table 1 for abbreviations.

${ }^{\mathrm{b}}$ Plant response in uncontaminated control soils with standard deviation ( $\mathrm{n}=3$ for root length and $\mathrm{n}=4$ for shoot growth).

${ }^{\mathrm{c}} \mathrm{CV}=\frac{\text { stdev }}{\text { mean }}$

n.d.=not determined 
Table 5. Pearson correlation coefficients $(r)$ and statistically significant differences $(p)$ between log EC50 values for plant toxicity assays and soil properties for five soils

\begin{tabular}{|c|c|c|c|c|c|c|c|c|c|c|c|c|}
\hline \multirow[t]{2}{*}{ - Plant assay } & \multicolumn{2}{|c|}{$\log$ Clay } & \multicolumn{2}{|c|}{$\log$ CEC } & \multicolumn{2}{|c|}{$\log \mathrm{Fe}-\mathrm{ox}$} & \multicolumn{2}{|c|}{$\log \mathrm{Al}-\mathrm{ox}$} & \multicolumn{2}{|l|}{$\mathrm{pH}$} & \multicolumn{2}{|c|}{$\log \mathrm{FSS}^{\mathrm{a}}$} \\
\hline & $r$ & $p$ & $r$ & $p$ & $r$ & $p$ & $r$ & $p$ & $r$ & $p$ & $r$ & $p$ \\
\hline Root elongation & 0.87 & NS & 0.70 & NS & 0.45 & NS & 0.20 & NS & 0.02 & NS & 0.96 & $<0.01$ \\
\hline Barley shoot growth & 0.77 & NS & 0.55 & NS & 0.62 & NS & 0.31 & NS & -0.14 & NS & 1.00 & $<0.001$ \\
\hline Tomato shoot growth & 0.56 & NS & 0.29 & NS & 0.85 & NS & 0.47 & NS & -0.38 & NS & 0.92 & $<0.05$ \\
\hline
\end{tabular}

${ }^{\mathrm{a}}$ The Freundlich sorption strength of vanadium in soil at a vanadium soil solution concentration of $2.5 \mathrm{mg} \mathrm{V} \mathrm{L}^{-1}$.

NS=Not Significant 


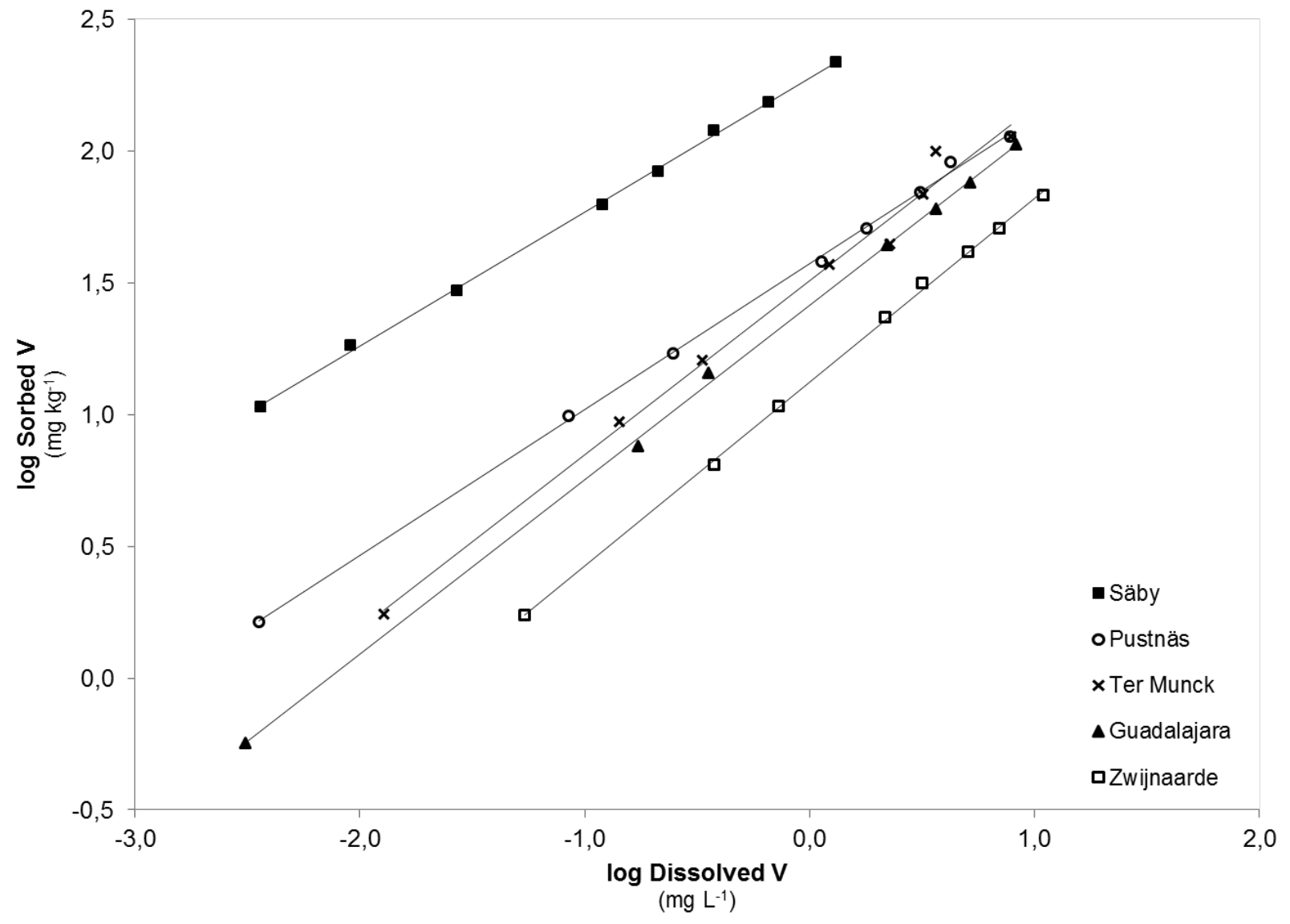

Figure 1. Sorption isotherms of added vanadate to soil suspensions of five soils. A background electrolyte of $0.01 \mathrm{M} \mathrm{NaNO}_{3}$ was used. Symbols are experimental values and the lines are fits to the Freundlich equation. 

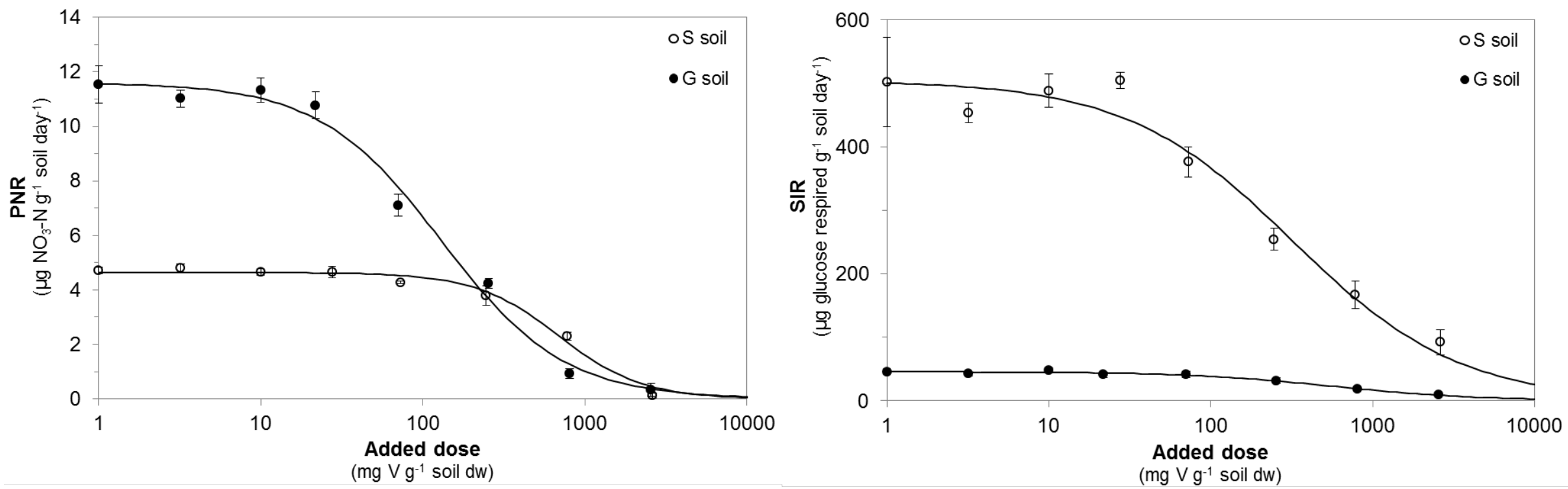

Figure 2. Response of microbial assays to vanadium in two different soils; Säby (S) and Guadalajara (G). Left: Dose-response curves for the nitrification assay, PNR= Potential nitrification rate. Right: Dose-response curves for the respiration assay, SIR= Substrate induced respiration. Symbols are observed results with standard deviation (based on 3 replicates) and the lines are fits. 

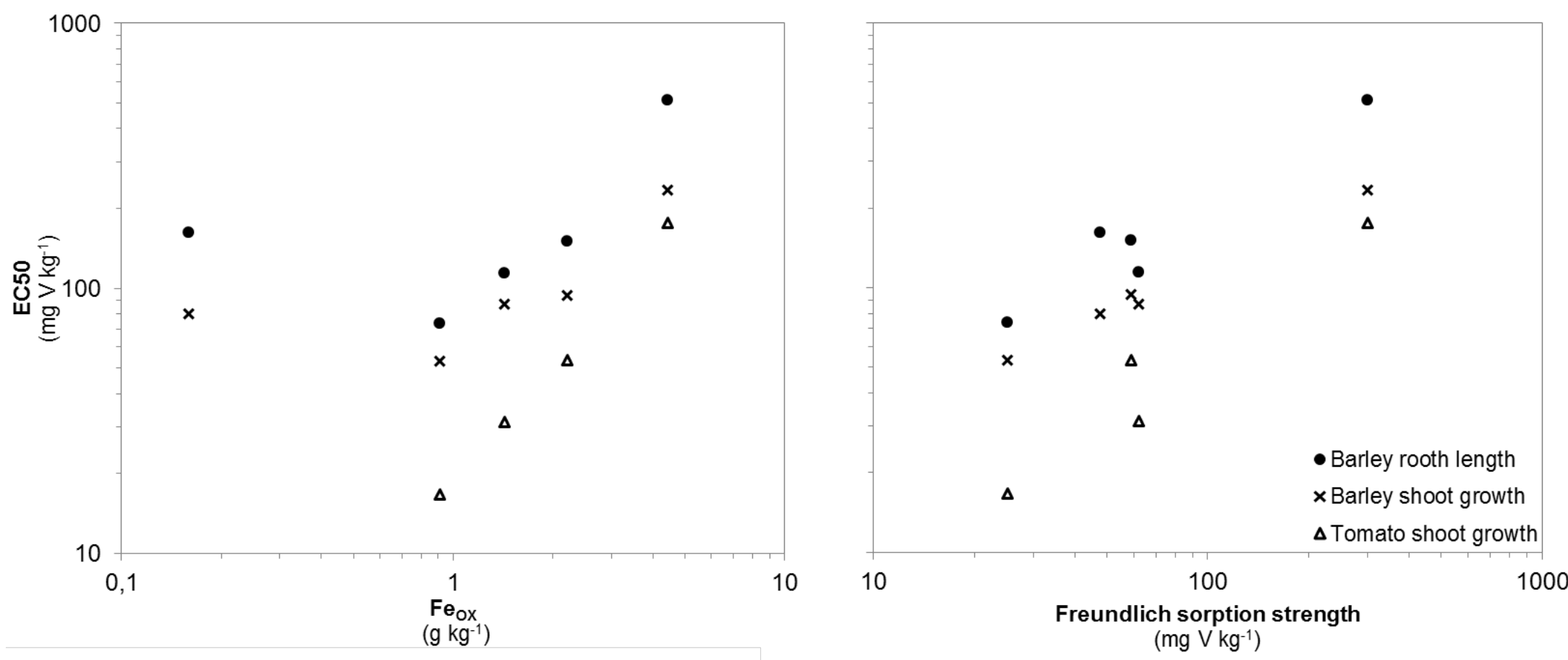

Figure 3. Toxicity of vanadium (EC50 for added vanadium) for three plant assays in relation to oxalate extractable iron (Fe $\mathrm{OXX}_{\mathrm{O}}$ left and to the Freundlich sorption strength (see text for definition) right, in five soils. Both axis are on a log scale. 

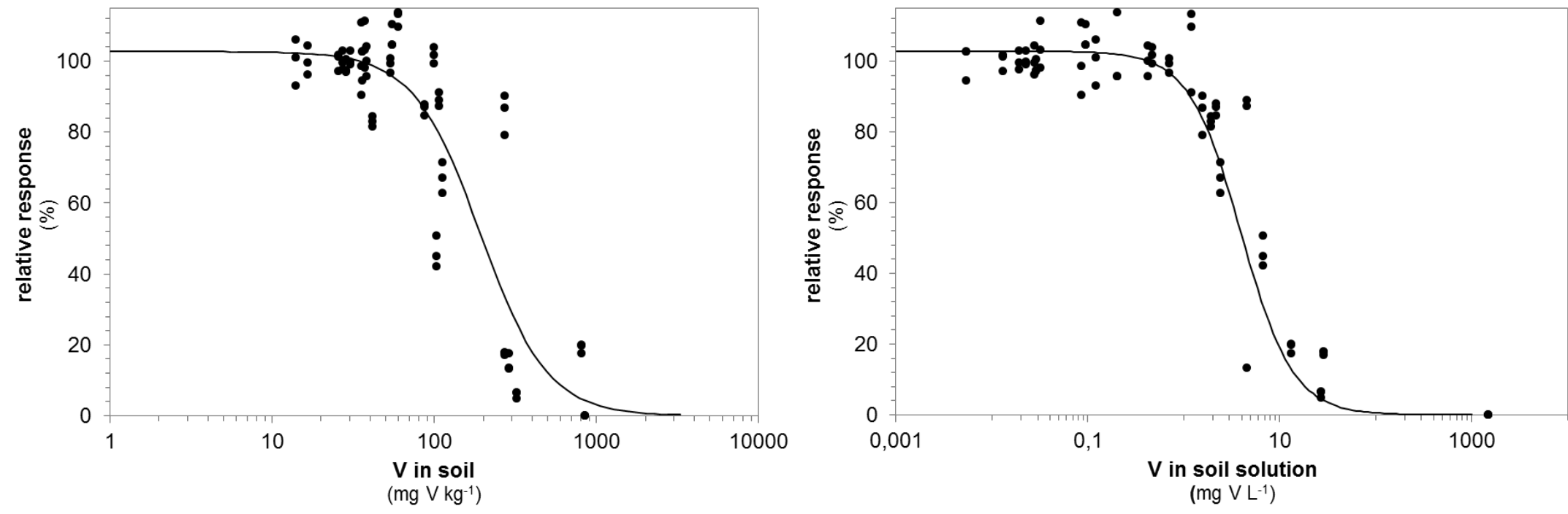

Figure 4. Relative response for root elongation assay (root length relative to control) across five soils plotted against the total aqua regia soluble vanadium concentration in soil (left graph) and against the total vanadium concentration in soil solution (right graph).

The markers are experimental values and curves are log-logistic lines fitted to the entire data-set. $\mathrm{R}^{2}$ adjusted is 0.79 (left) and 0.94 (right). 